\title{
Cholesteryl Ester Transfer Protein (CETP) expression does not affect glucose homeostasis and insulin secretion: studies in human CETP transgenic mice
}

\author{
Helena F. Raposo', Emerielle C. Vanzela', Jairo A. Berti ${ }^{1,2}$ and Helena C F Oliveira ${ }^{1 *}$
}

\begin{abstract}
Background: Cholesteryl ester transfer protein (CETP) is a plasma protein that mediates the exchange of triglycerides for esterified cholesterol between HDL and apoB-lipoproteins. Previous studies suggest that CETP may modify glucose metabolism in patients or cultured cells. In this study, we tested if stable CETP expression would impair glucose metabolism.

Methods: We used human CETP transgenic mice and non-transgenic littermate controls (NTg), fed with control or high fat diet, as well as in dyslipidemic background and aging conditions. Assays included glucose and insulin tolerance tests, isolated islets insulin secretion, tissue glucose uptake and adipose tissue GLUT mRNA expression.

Results: CETP expression did not modify glucose or insulin tolerance in all tested conditions such as chow and high fat diet, adult and aged mice, normo and dyslipidemic backgrounds. Fasting and fed state plasma levels of insulin were not differ in CETP and NTg mice. Direct measurements of isolated pancreatic islet insulin secretion rates induced by glucose $(11,16.7$ or $22 \mathrm{mM}), \mathrm{KCl}(40 \mathrm{mM})$, and leucine $(10 \mathrm{mM})$ were similar in NTg and CETP mice, indicating that CETP expression did not affect $\beta$-cell function in vivo and ex vivo. Glucose uptake by insulin target tissues, measured in vivo using ${ }^{3} \mathrm{H}$-2-deoxyglucose, showed that CETP expression had no effect on the glucose uptake in liver, muscle, perigonadal, perirenal, subcutaneous and brown adipose tissues. Accordingly, GLUT1 and GLUT4 mRNA in adipose tissue were not affected by CETP.
\end{abstract}

Conclusions: In summary, by comparing the in vivo all-or-nothing CETP expressing mouse models, we demonstrated that CETP per se has no impact on the glucose tolerance and tissue uptake, global insulin sensitivity and beta cell insulin secretion rates.

Keywords: Cholesteryl ester transfer protein (CETP), Glucose homeostasis, Insulin sensitivity, Glucose uptake

\section{Background}

Type 2 Diabetes mellitus (T2DM) is a metabolic disorder characterized by high glucose plasma levels and insulin resistance [1]. Insulin resistant diabetic patients commonly present dyslipidemia, which is generally characterized by high triglycerides and low HDL plasma levels [2]. The HDL-cholesterol level is recognized as a

\footnotetext{
* Correspondence: ho98@unicamp.br

${ }^{1}$ Department of Structural and Functional Biology, Institute of Biology, State University of Campinas, Unicamp - Cidade Universitária Zeferino Vaz. Rua Monteiro Lobato, 255, Campinas, SP CEP 13083-862, Brazil

Full list of author information is available at the end of the article
}

protective factor against atherosclerosis and cardiovascular diseases because HDL promotes reverse cholesterol transport from the periphery to the liver and acts as anti-inflammatory, antioxidant and anti-thrombotic lipoprotein [3].

Cholesteryl ester transfer protein (CETP) is a plasma protein that mediates the exchange of triglycerides from apoB-lipoproteins for esterified cholesterol from HDL [4]. In this way, CETP promotes reduction of plasma HDL-cholesterol and, thus, may increase the risk of atherosclerosis. Therefore, in the last decades, efforts have been made to inhibit CETP activity as an anti- 
atherogenic intervention. Although these CETP inhibitors increase HDL-cholesterol and decrease LDLcholesterol concentrations, they failed to prove their benefits in reducing cardiovascular disease mortality [5-7].

There are evidences that suggest a relationship between CETP and glucose homeostasis, although this issue has been a matter of debate. Clinical studies associated higher CETP levels to T2DM risk [8] and showed that CETP polymorphism may modulate insulin sensitivity $[9,10]$. Individuals with higher CETP mass present higher values of fasting insulin and HOMA insulin resistance index compared with individuals with lower CETP mass. A post-hoc analysis of the ILLUMINATE trial linked CETP inhibition by torcetrapib to a significant improvement in glycemic control [11].

On the other hand, comparison of subject groups with distinct insulin sensitivity (lean $v s$. obese and rested $v s$. exercised) found no association between CETP and insulin sensitivity [12]. In addition, through a genome-wide approach, Sladek et al. [13] performed a systematic search looking for associations between T2DM risk and almost 400,000 polymorphisms. They did not find any significant associations between major genes or proteins associated with HDL metabolism and risk of T2DM or glucose intolerance. Furthermore, a recent clinical trial using a potent CETP inhibitor, dalcetrapib, failed to improve insulin sensitivity in patients [14].

In the opposite direction, Ju et al. [15] found that expressing human CETP in 3T3-L1 cells resulted in increased glucose uptake, suggesting that CETP expression would improve insulin sensitivity. Accordingly, Cappel et al. [16] reported that simian CETP expression protects against insulin resistance in obese female mice.

In light of these conflicting evidences of the role of CETP on the glucose and insulin homeostasis, we took the advantage of the human CETP transgenic mice model, expressing physiological levels of CETP, and compared them with their CETP non-expressing littermate controls to further investigate this issue.

\section{Results}

Human CETP transgenic mice were used to verify the effects of CETP long-term expression over glucose metabolism. Heterozygous CETP transgenic (CETP-Tg) mice expressing a human natural promoter-driven CETP transgene [17] were compared to their non-transgenic littermates mice. These CETP transgenic mice present human like plasma levels of CETP $(\sim 2 \mathrm{ug} / \mathrm{ml})$ [18], modest reductions of HDL-cholesterol plasma levels [19], authentic tissue pattern of expression and regulation of gene expression [17, 20].

As shown in Fig. 1, the glycemic curves after a glucose load (GTT) in female (Fig. 1a) and male (Fig. 1b) mice and after an insulin load (ITT) were similar between
CETP and NTg mice. Therefore, CETP expression apparently does not modify either glucose tolerance or insulin sensitivity. To confirm these results, we also measured plasma insulin levels in both fasting and fed states in male and female mice (Table 1) and found no effects of CETP expression on the insulinemia. Next we evaluated the ex vivo insulin secretion by isolated pancreatic islets stimulated by several secretagogues (Fig. 2). Glucose (11 mM or $16.7 \mathrm{mM}), \mathrm{KCl}(40 \mathrm{mM})$, and leucine $(10 \mathrm{mM})$ induced insulin secretion in a similar manner in islets isolated from NTg or CETP mice, indicating that CETP expression does not affect $\beta$-cell function.

Tissue specific sensitivity to insulin was directly determined in vivo by measuring glucose uptake by white (WAT) and brown (BAT) adipose tissues, liver and muscle after a bolus ip injection of ${ }^{3} \mathrm{H}$-2-deoxiglucose $\left({ }^{3} \mathrm{H}-2 \mathrm{DG}\right)$ dissolved in a glucose solution ( $\left.2 \mathrm{~g} / \mathrm{Kg} \mathrm{BW}\right)$. As shown in Fig. 3, CETP expression had no effects on the glucose tissue uptake when compared to NTg mice, as well as it did not modify the plasma clearance of ${ }^{3} \mathrm{H}$ 2DG and glucose levels. Since a previous study [15] reported that $3 \mathrm{~T} 3$ mouse adipocytes transfected with CETP cDNA presented increased glucose uptake, we checked the expression of genes encoding the glucose transporters GLUT1 (Scl2a1) and GLUT4 (Scl2a4) mRNA levels in the mice adipose tissue (Fig. 4). In agreement with the results of in vivo glucose uptake, CETP expression did not change GLUT gene expression in the adipose tissue depots.

To further investigate if CETP would affect glucose metabolism in the presence of other metabolic complications, glucose tolerance tests were performed in aged or dyslipidemic backgrounds. For this purpose, we crossbred CETP mice with a model of hypertriglyceridemia due to overexpression of apolipoprotein CIII $\left(\mathrm{CETP}^{+/-} / \mathrm{CIII}^{-/+}\right)$and with a model of hypercholesterolemia due to the disruption of the LDL receptor gene $\left(\mathrm{CETP}^{+/-} / \mathrm{LDLr}^{-/+}\right)$. These crosses were previously studied and exhibit marked hypertriglyceridemia and mild hypercholesterolemia, respectively [21, 22]. Table 2 shows that CETP expression had no effect on the glucose tolerance in male aged (18 month old), hypertriglyceridemic (apoCIII overexpressing) or LDL receptor defective mice. In addition, possible effects of CETP on glucose homeostasis were also investigated in the context of a high fat diet (60\% Kcal as saturated fat) for 3 months. As shown in Fig. 5, CETP expression did not affect glucose tolerance (Fig. 5a), insulin sensitivity (Fig. 5b) and islet insulin secretion (Fig. 5c) in high fat fed mice. As expected, insulin secretion was higher in all mice fed with a high fat diet compared to chow diet. However, the comparison between NTg and CETP mice showed no significant differences in insulin secretion (Fig. 5c). 

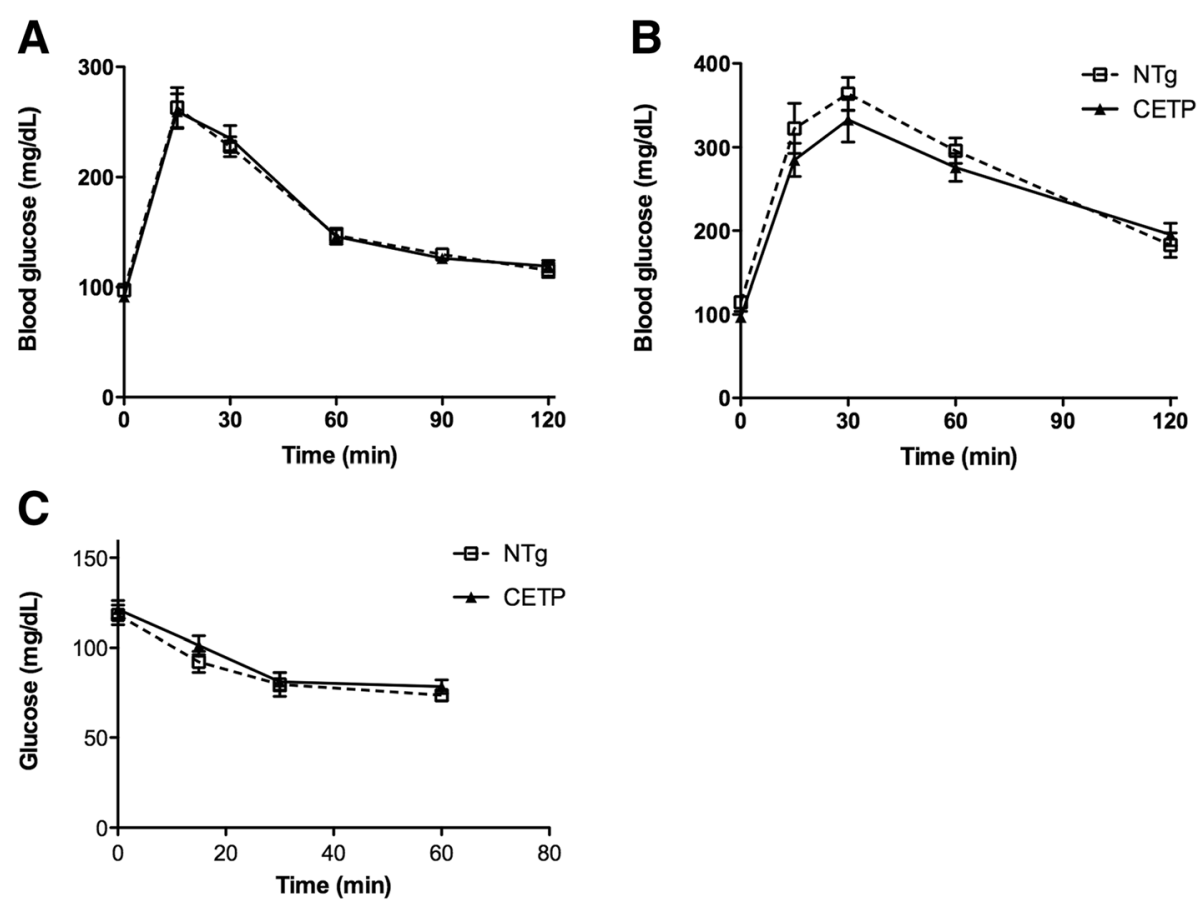

Fig. 1 CETP expression does not affect either glucose tolerance or insulin sensitivity. Glucose tolerance test (GTT) was performed in 5-9 month old NTg and CETP female (a: oral GTT) ( $n=8$ each group) and male (b: ip GTT) ( $n=5$ each group) mice, fasted for $12 \mathrm{~h}$. Intraperitoneal (ip) insulin-tolerance test (ITT) was performed in fed mice (c) (NTg: $n=2$ male and 2 female, CETP: $n=2$ male and $n=3$ female). Values are expressed as mean \pm SE. Student's $t$ test: non-significant

\section{Discussion}

Several previous studies have suggested a relationship between CETP and glucose metabolism $[8-10,15,16]$ including a putative positive effect of pharmacological inhibition of CETP on the glycemic control [11, 23]. Thus, in this study we used mice expressing a human CETP gene to investigate the long-term consequences of CETP on the glucose homeostasis. Because wild type mice do not express this gene [24], CETP transgenic mice are useful to explore CETP effects in a complex in vivo biological system. We investigated the main steps of glucose homeostasis and verified that CETP expression causes no significant alterations in glucose tolerance, fasting and fed plasma insulin levels, global insulin sensitivity, pancreatic islet insulin secretion and glucose tissue uptake. Previous data from our group had already

Table 1 CETP expression has no effect on insulin plasma levels

\begin{tabular}{llll}
\hline & & \multicolumn{2}{l}{ Plasma insulin $(\mathrm{ng} / \mathrm{ml})$} \\
\cline { 3 - 4 } & & $\mathrm{NTg}$ & CETP \\
\hline Female & Fast & $0.330 \pm 0.023(9)$ & $0.380 \pm 0.040(5)$ \\
& Fed & $0.488 \pm 0.082(9)$ & $0.970 \pm 0.604(5)$ \\
Male & Fast & $0.240 \pm 0.108(3)$ & $0.447 \pm 0.047(4)$ \\
& Fed & $0.464 \pm 0.024(3)$ & $0.619 \pm 0.066(4)$ \\
\hline
\end{tabular}

Insulin plasma level of male and female CETP expressing mice and their littermates' controls in fed state and after $12 \mathrm{~h}$ fast. Values are expressed as mean \pm SE (n). Student's $t$ test: NTg vs. CETP: non-significant shown no differences in the plasma levels of glucose and insulin, either in fasted or fed state, in CETP transgenic compared to NTg mice [25]. Therefore, according to our data, the CETP expression does not impose any disadvantage for glucose homeostasis maintenance.

Ju et al. have previously shown that in vitro human CETP expression in adipocyte 3T3-L1 mouse cell line (driven by a heterologous viral promoter) resulted in enhanced insulin-mediated glucose uptake [15]. Here, we demonstrate that in vivo human CETP expression driven by its natural promoter did not affect glucose uptake by adipose and other insulin target tissues. It is likely that the in vivo hormonal milieu present in the whole organism are responsible for these distinct results.

Briand et al. [26] demonstrated in hamsters that CETP inhibition by torcetrapib treatment significantly reduced blood glucose and plasma insulin levels after a high fat/high cholesterol diet. ${ }^{3} \mathrm{H}-2 \mathrm{DG}$ uptake was reduced in adipose tissues but increased in soleus, liver and heart of these torcetrapib treated hamsters. However, the pattern of CETP tissue expression in hamsters markedly differs from that observed in the transgenic mice, which is similar to humans $[17,27]$. Contrary to the effect observed in hamsters, torcetrapib treatment of humans induced an increase in post-prandial plasma insulin levels [23]. 


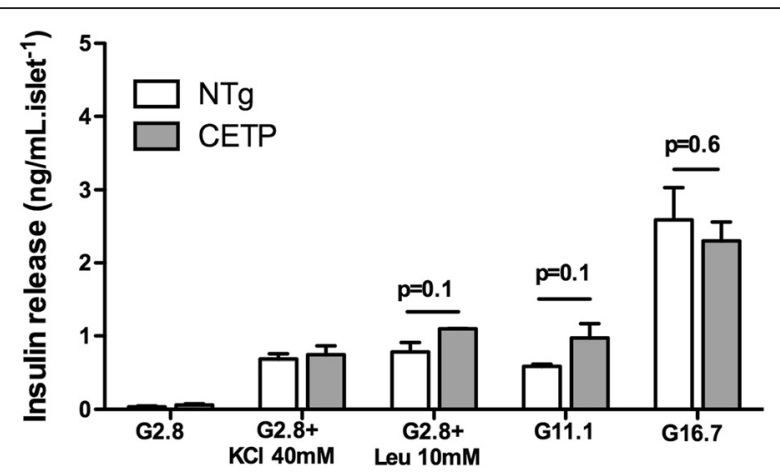

Fig. 2 CETP expression does not impact on insulin secretion. Freshly isolated islets from female NTg (white columns) or CETP (gray columns) mice with 7 month of age were incubated in Krebs bicarbonate buffer containing $5.6 \mathrm{mmol} / \mathrm{l}$ glucose for $30 \mathrm{~min}$ at $37^{\circ} \mathrm{C}$ (5 islets/well, four replicates in each condition). Then, the buffer was replaced by fresh buffer containing $2.8 \mathrm{mM}$ glucose, $2.8 \mathrm{mM}$ glucose plus $\mathrm{KCl}(40 \mathrm{mM})$, $2.8 \mathrm{mM}$ glucose plus leucine (10 mM), $11 \mathrm{mM}$ glucose or $16.7 \mathrm{mM}$ glucose. After $1 \mathrm{~h}$ incubation, buffer was collected and insulin was measured by radioimmunoassay. Insulin release was normalized by islet number. Values are expressed as mean \pm S.E. $n=4-6$ mice in 3 independent experiments. Student's t test: non-significant

Cappel et al. [16] used a mouse model expressing a simian CETP gene under control of a constitutive promoter to demonstrate that CETP expression protects against diet induced insulin resistance in obese female mice, but not in male or in chow fed mice. They postulate that CETP would increase cholesterol delivery to the liver, increasing bile acids excretion into the gut. These effects would initiate signaling pathways that improve insulin sensitivity, such as those observed after an oral taurodeoxycholic acid treatment [28]. Nevertheless, the CETP transgenic mice used here present no alterations in bile acids secretion into the bile and fecal excretion [29]. In addition, bile acids mass excretion is not altered in torcetrapib-treated hamsters [26].

Siebel et al. [23] showed that plasma post-CETP inhibition promoted glucose-stimulated insulin secretion in MIN6N8 insulinoma cells that were pretreated with oxidized (ox) LDL. The authors attributed these effects to the higher concentrations of HDL-cholesterol in the incubation medium rather than to the low CETP levels. In fact, it was previously shown that oxLDL exerts deleterious effects on beta cells, such as activation of JNK pathway and apoptosis, which are countered by HDL particles [30]. One way by which high HDL-cholesterol levels would improve the efficiency of insulin secretion could be through removing cholesterol from the cell membrane. As previously demonstrated by our group, both abnormally high or low islet cholesterol content impairs glucose stimulated insulin secretion, while its normalization improves it $[31,32]$. It is important to emphasize that CETP expression decreases HDLcholesterol levels in a gene dosage manner [19]. The mouse model used here exhibits about 15-20\% lower HDL-cholesterol levels when compared with NTg mice $[19,22]$. Even though, here we verified no differences in insulin secretion of freshly isolated islets from NTg or CETP mice.

Lopez-Rios et al. [10] have hypothesized that individuals with higher CETP activity have HDL particles enriched in triglycerides, which would increase the flux of free fatty acid to the liver and decrease hepatic sensitivity to insulin, and thus, predispose to diabetes. According to De Vries et al. [8], CETP mass and activity was higher in T2DM subjects, suggesting that lowering plasma CETP could ameliorate diabetes-associated cardiovascular risk. Alongside, Barter et al. [11] reported that treatment with torcetrapib improves glycemic control in atorvastatin-treated patients with T2DM. Since literature shows that CETP have worse outcomes in unhealthy patients, here CETP effects were also investigated in mice treated with high fat diet, with hyperlipidemic background, and also in aged mice. However, our data show no harm of CETP stable expression even when metabolism was challenged to more adverse conditions. Since different results were found with CETP expressing mice and with CETP inhibitor torcetrapib $[11,23]$, it is also possible to speculate about a direct effect of this drug on the glycemic control, independently of the CETP levels. Our data is in agreement with previous work that showed that CETP activity does not correlate with parameters of insulin sensitivity in nondiabetic individuals [12]. A conciliatory view of most conflicting clinical and experimental data is that CETP per se is not relevant to glucose homeostasis/insulin sensitivity, but actually the HDL-cholesterol levels and perhaps the HDL functionality is important to regulate glucose metabolism and modulate diabetes risk [33]. As mentioned before, the CETP mouse model studied here present modest changes in HDL plasma levels.

\section{Conclusions}

In conclusion, by comparing in vivo all-or-nothing human CETP mouse model, our data demonstrate that CETP per se does not modulate glycemic control and insulin secretion in young and aged healthy mice, as well as in dyslipidemic and high fat fed mice.

\section{Methods}

Animals

All experimental protocols were approved by the university's Committee for Ethics in Animal Experimentation (CEUA/UNICAMP, protocol \# 1107-1) and are in accordance with the "Principles of Laboratory Animal Care" (NIH publication no. 85-23, revised 1985). In this study, experiments were performed in 5 to 9 months old mice (adult), and in an additional aged group of 

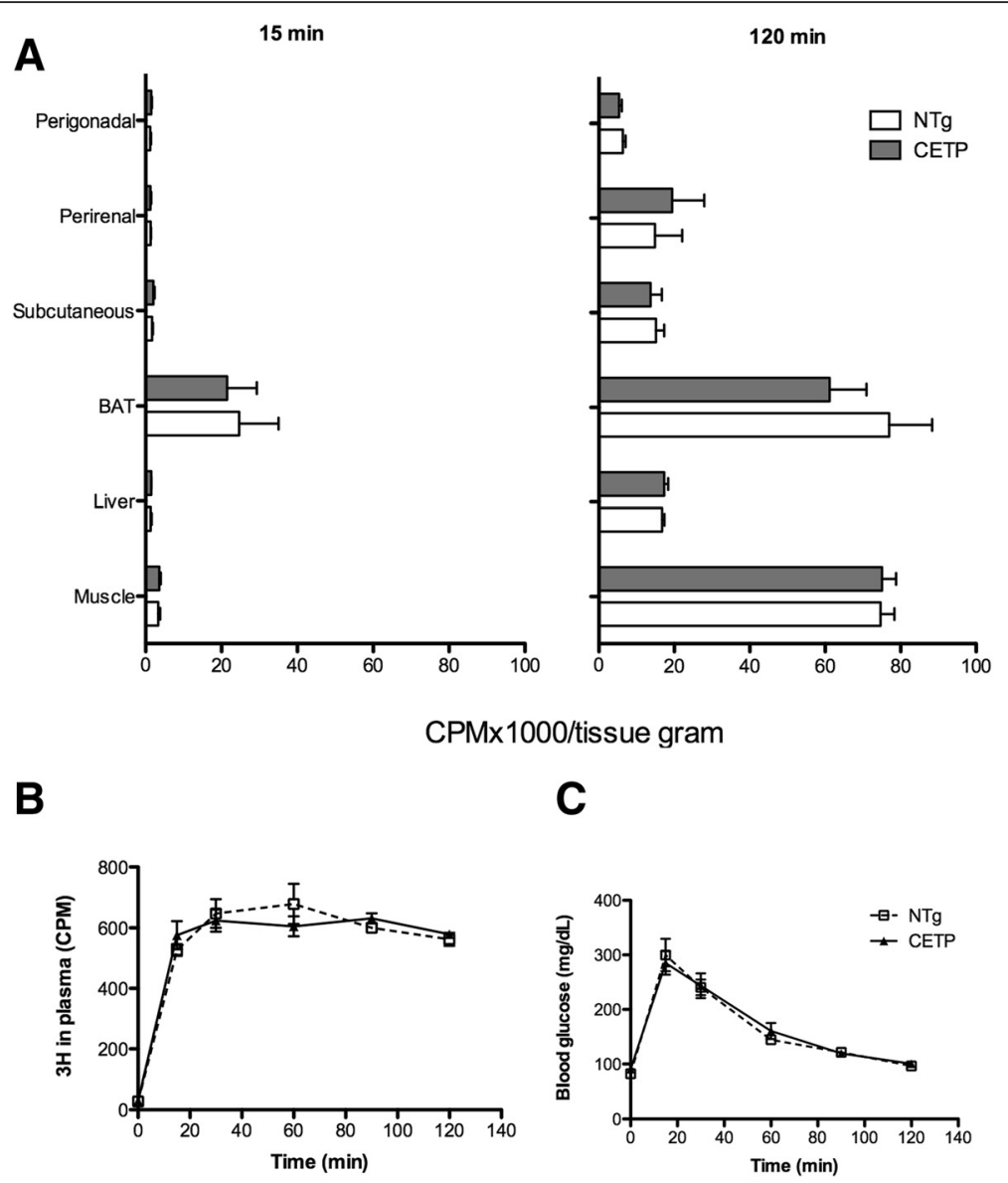

Fig. 3 CETP expression has no effect on tissue glucose uptake. Perigonadal, perirenal, subcutanous and brown (BAT) adipose tissue, liver and muscle glucose uptake was measured in vivo, 15 min and $2 \mathrm{~h}$ after an intraperitoneal injection of glucose $(2 \mathrm{~g} / \mathrm{Kg} \mathrm{BW})$ and ${ }^{3} \mathrm{H}$-2-deoxiglucose $(150 \mu \mathrm{Ci} / \mathrm{Kg} \mathrm{BW})$ in 5 month old NTg and CETP female mice (a). Blood was collected ${ }^{3} \mathrm{H}$ activity was determined in plasma (b) and glucose (c) in blood. Mean \pm SE ( $n=3-6$ per group). Student's $t$ test: non-significant

18 months old mice. Both male and female mice were used for the experiments. Heterozygous CETP transgenic (CETP-Tg) mice expressing a human natural promoter-driven CETP transgene, line 5203 [17] and non-transgenic littermates mice were used. CETP-Tg mice were crossbred with human apolipoprotein CIII transgenic mice, line 3707 [34] to generate apoCIII and apoCIII/CETP. In addition, LDL receptor $\left(\mathrm{LDLr}^{-/-}\right)$ knockout mice [35] and CETP-Tg mice were crossbred to generate $\mathrm{LDLr}^{-/+}$and $\mathrm{CETP}^{+/-} / \mathrm{LDLr}^{-/+}$mice. CETPexpressing mice were screened by assaying plasma CETP activity, as previously described [18]. The apoCIII transgenic mice had plasma triacylglycerol levels above $300 \mathrm{mg} / \mathrm{dL}$ and $\mathrm{LDLr}^{-/-}$mice had plasma cholesterol levels above $200 \mathrm{mg} / \mathrm{dL}$, whereas the non-transgenic mice had both triacylglycerol and cholesterol levels below $100 \mathrm{mg} / \mathrm{dL}$. Mice were housed in a temperaturecontrolled room $\left(22 \pm 1{ }^{\circ} \mathrm{C}\right)$ on a $12 \mathrm{~h}$ light/dark cycle and had free access to food and water. The chow diet (Nuvital CR1, Colombo, Brazil) was offered from weaning and its composition was (\% by weight) $23 \%$ protein, $4.5 \%$ total fat, $33 \%$ carbohydrates and $21 \%$ fiber, with a total of $263 \mathrm{kcal} / 100 \mathrm{~g}$. The high fat diet was offered from 2 to 5 months old and its composition was (\% by weight) $14 \%$ protein, $35 \%$ total fat (59\% of calories), $41 \%$ carbohydrates and $5 \%$ fiber, with a total of $536 \mathrm{kcal} / 100 \mathrm{~g}$.

\section{Blood glucose and plasma insulin levels}

Blood glucose concentrations were measured using a glucose analyzer (Accu-Chek Advantage, Roche Diagnostic, Switzerland). Plasma insulin levels were determined by ELISA (Ultra Sensitive Mouse Insulin ELISA Kit, Christal Chem, USA) according to the manufacturer instructions.

\section{Glucose tolerance test (GTT) and insulin tolerance test (ITT)}

Female mice were submitted to an oral glucose tolerance test after $12 \mathrm{~h}$ fast. Basal blood sample was collected from the tail tip ( $\mathrm{t}=0 \mathrm{~min})$ and a glucose load of $1.5 \mathrm{~g} /$ 

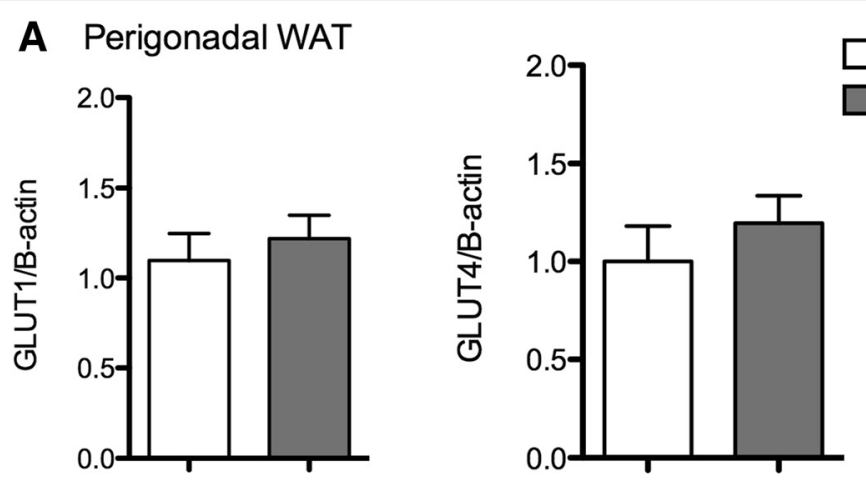

B Subcutaneous WAT
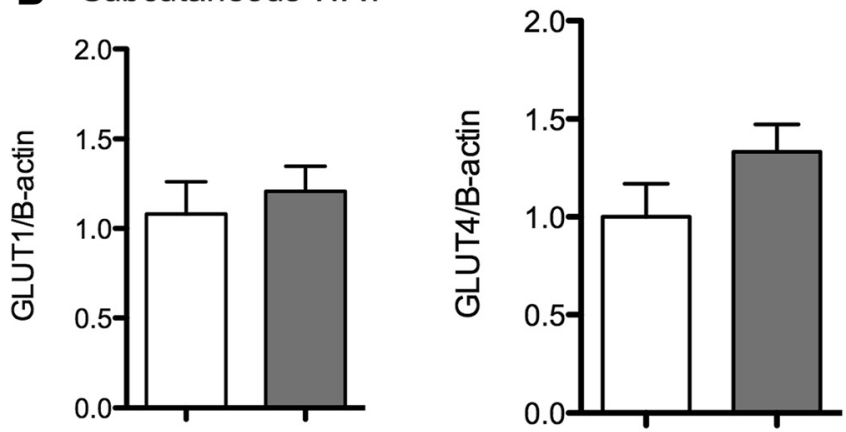

\section{BAT}
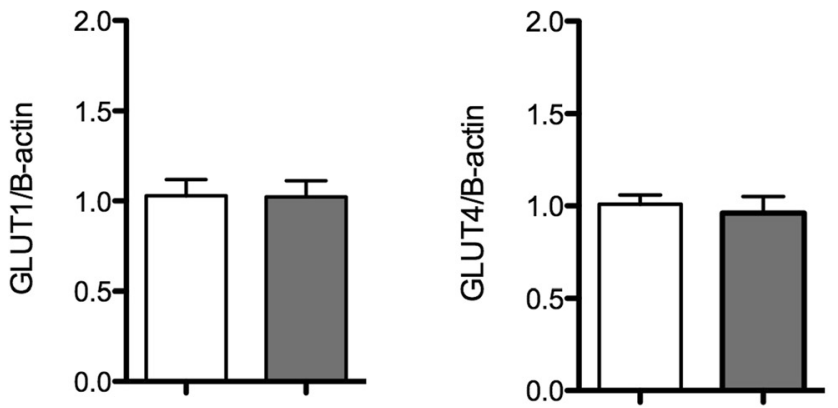

Fig. 4 CETP expression does not affect glucose transporters gene expression in adipose tissues. SCl2a1 (encoding GLUT1) and SCl2a1 (encoding GLUT4) mRNA expression were determined in visceral (a), subcutaneous (b) and brown (c) adipose tissue depots of 5 months old non-transgenic (NTg) and CETP female mice. Gene expression was quantified by real-time RT-PCR using the $\Delta \Delta C T$ method normalized to $\beta$-actin and then expressed relative to the control (NTg) group. Mean \pm SE ( $n=7-12$ per group). Student's $t$ test: non-significant

$\mathrm{kg}$ body weight was then administered by oral gavage. Additional blood samples were collected at 15, 30, 60 and $90 \mathrm{~min}$ after glucose ingestion. Male mice were submitted to an intraperitoneal $(i p)$ glucose tolerance test. After $12 \mathrm{~h}$ fast, mice were injected with a glucose load of $2 \mathrm{~g} / \mathrm{kg}$ body weight and blood samples were collected at $0,15,30,60$ and $120 \mathrm{~min}$. For the ITT, blood was taken from fed female and male mice immediately before insulin ip injection $[0.75 \mathrm{U} / \mathrm{Kg}$ body weight of human insulin (Human insulin R, Eli Lilly and Company)] and at the times 10, 15, 30 and $60 \mathrm{~min}$ for glucose analyses.

\section{Pancreatic islet isolation and insulin secretion}

The pancreatic islets were isolated from fed mice by collagenase digestion $(0.8 \mathrm{mg} / \mathrm{mL}$; Type V; Sigma C9263) (adapted from [36]), rinsed tree times in Hanks Solution $[137 \mathrm{mmol} / \mathrm{l} \quad \mathrm{NaCl} ; \quad 5.4 \mathrm{mmol} / \mathrm{l} \quad \mathrm{KCl} ; 0.8 \mathrm{mmol} / \mathrm{l}$ $\mathrm{MgSO}_{4} \cdot 7 \mathrm{H}_{2} \mathrm{O} ; \quad 0.34 \mathrm{mmol} / \mathrm{l} \quad \mathrm{Na}_{2} \mathrm{HPO}_{4} ; \quad 0,44 \mathrm{mmol} / \mathrm{l}$ $\mathrm{KH}_{2} \mathrm{PO}_{4} ; 1.26 \mathrm{mmol} / \mathrm{l} \mathrm{CaCl} .2 \mathrm{H}_{2} 0 ; 4.2 \mathrm{mmol} / \mathrm{l} \mathrm{NaHCO}$; $\mathrm{pH} 7.4$ plus $5.6 \mathrm{mmol} / \mathrm{l}$ glucose and $0.1 \%(\mathrm{w} / \mathrm{v}) \mathrm{BSA}$ ] to remove the enzyme from medium and then selected manually under a microscope to exclude any contaminating tissues. After isolation, batches of 5 islets each were pre-incubated in Krebs-Ringer bicarbonate buffer 
Table 2 CETP expression has no effect on glucose tolerance in aged, hypertriglyceridemic or hypercholesterolemic mice

\begin{tabular}{|c|c|c|}
\hline Model & $\begin{array}{l}\mathrm{AUC} \pm \mathrm{SE} \\
\left(\mathrm{mg} \cdot \mathrm{dl}^{-1} \cdot \mathrm{min}\right)\end{array}$ & $\begin{array}{l}\mathrm{n} \\
\text { male/female }\end{array}$ \\
\hline Aged-NTg & $10933 \pm 1570$ & $4 / 0$ \\
\hline Aged-CETP & $11737 \pm 1069(7)$ & $7 / 0$ \\
\hline ApoCIIII/+ & $22777 \pm 3238$ & $3 / 1$ \\
\hline ApoCIIII ${ }^{-/+} /$CETP $^{-/+}$ & $25114 \pm 9466$ & $1 / 2$ \\
\hline $\operatorname{LDLr}^{-/+}$ & $15920 \pm 2587$ (4) & $0 / 4$ \\
\hline $\mathrm{LDLr}^{-/+} / \mathrm{CETP}^{+/-}$ & $12951 \pm 407(5)$ & $2 / 3$ \\
\hline
\end{tabular}

Area under the curve (AUC) of oral glucose tolerance test in aged (18 month old), apo CIII transgenic and LDL receptor deficient $\left(\mathrm{LDLr}^{-/+}\right)$mice expressing or not CETP, fasted for $12 \mathrm{~h}$. At time zero, mice received a glucose dose of $1.5 \mathrm{~g} / \mathrm{kg}$ body weight by gavage. Samples for glucose determination were collected from the tail tip at $0,15,30,60$ and $120 \mathrm{~min}$. Values are expressed as mean \pm SE (n: male and female pooled data). Student's $t$ test for all comparisons: non-significant

(KRBB) containing: $115 \mathrm{mmol} / \mathrm{l} \mathrm{NaCl}, 5 \mathrm{mmol} / \mathrm{l} \mathrm{KCl}$, $10 \mathrm{mmol} / 1 \mathrm{NaHCO}_{3}, 2.5 \mathrm{mmol} / \mathrm{l} \mathrm{CaCl}_{2} \cdot 2 \mathrm{H}_{2} \mathrm{O}, 1 \mathrm{mmol} / \mathrm{l}$ $\mathrm{MgCl}_{2} \cdot 6 \mathrm{H}_{2} \mathrm{O}$ and $15 \mathrm{mmol} / \mathrm{l}$ HEPES, pH 7.4 plus $5.6 \mathrm{mmol} / \mathrm{l}$ glucose and $0.3 \%(\mathrm{w} / \mathrm{v}) \mathrm{BSA}$ for $30 \mathrm{~min}$ at $37{ }^{\circ} \mathrm{C}$. Then, the buffer was replaced by fresh buffer containing $2.8 \mathrm{mM}$ glucose, $2.8 \mathrm{mM}$ glucose plus $\mathrm{KCl}$ (40 mM), $2.8 \mathrm{mM}$ glucose plus leucine (10 mM), $11 \mathrm{mM}$ glucose, $16.7 \mathrm{mM}$ glucose or $22.2 \mathrm{mM}$ glucose. After $1 \mathrm{~h}$ incubation, buffer was collected and insulin was measured by radioimmunoassay [37] using rat insulin as standard, human recombinant ${ }^{125}$ I-Insulin (PerkinElmer) and anti-insulin from guinea pig. Insulin release was normalized by islet number.

\section{Glucose tissue uptake (in vivo)}

After $12 \mathrm{~h}$ fasting, mice were injected (i.p.) with glucose ( $2 \mathrm{~g} / \mathrm{Kg}$ body weight) plus ${ }^{3} \mathrm{H}$-2-deoxiglucose $(150 \mu \mathrm{Ci} /$ $\mathrm{Kg}$ body weight) [38]. Blood sample were collected from the tail tip before (time 0 ) and after the injection at 15 , 30,60 , 90 e $120 \mathrm{~min}$ for glucose and radioactivity determination. At $15 \mathrm{~min}$ and $120 \mathrm{~min}$, groups of mice were anesthetized and killed by exsanguination. Tissues [liver, muscle (gastrocnemius + soleus), perigonadal, perirenal, subcutaneous and brown adipose tissue] were collected, washed with saline, and digested in a tissue solubilizer solution (GE Healthcare-Amersham). Non-aqueous cintilation liquid (GE Healthcare-Amersham) were added
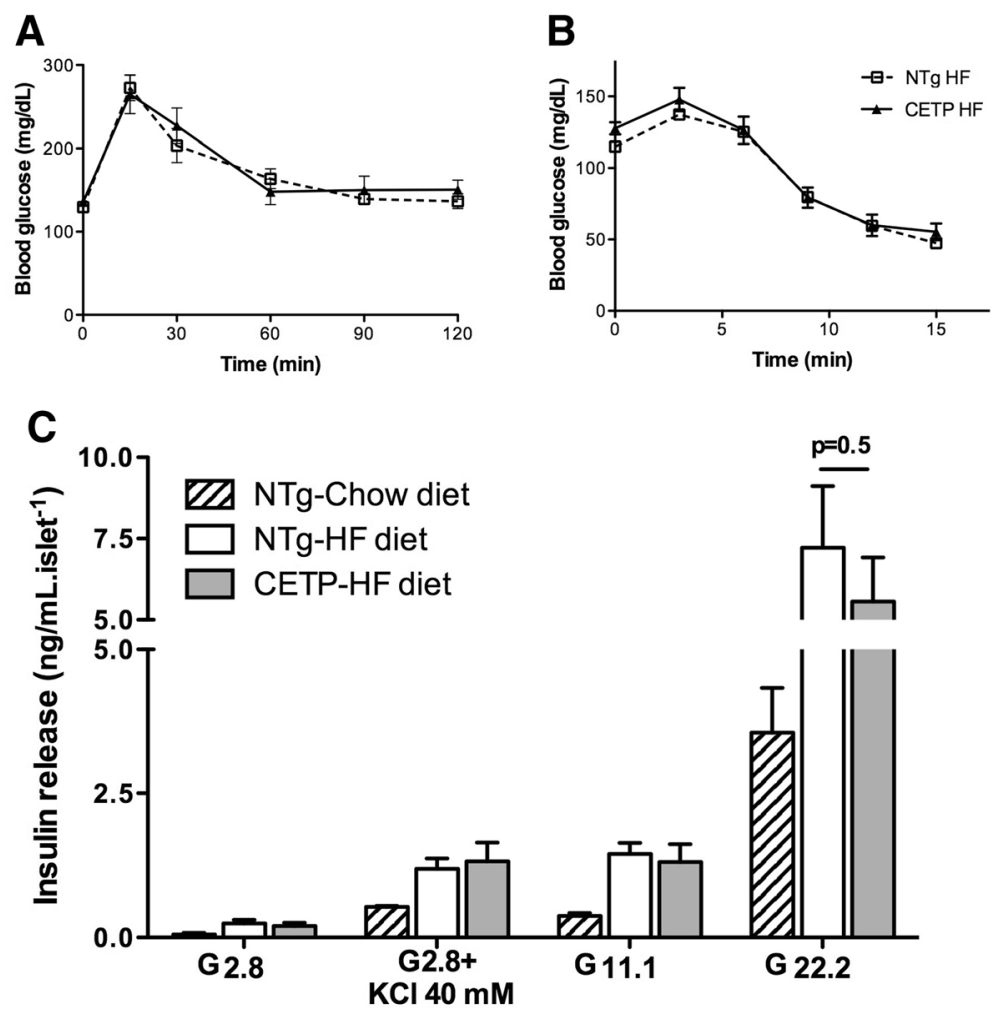

Fig. 5 CETP expression does not affect glucose tolerance, insulin sensitivity and secretion in obese mice. Glucose tolerance test performed in NTg and CETP female mice treated with high fat diet from 2 to 5 months of age, after 12 hs of fasting, $n=5-7$ per group (a). Intraperitoneal (ip) insulin-tolerance test (ITT) was performed after $3 \mathrm{~h}$ fasting, $\mathrm{n}=6-8$ (b). Freshly isolated islets from NTg mice fed with chow diet (black columns), and NTg (white columns) and CETP (gray columns) mice fed with high fat diet were incubated in the presence of $2.8 \mathrm{mM}$ glucose, $2.8 \mathrm{mM}$ glucose plus $\mathrm{KCl}(40 \mathrm{mM}), 11 \mathrm{mM}$ glucose or $22.2 \mathrm{mM}$ glucose, as described in Fig. 2, $\mathrm{n}=2-4$ female mice in two independent experiments (c). Values are expressed as mean \pm S.E. Student's $t$ test: non-significant 
Table 3 Specific primers sequences used for Real-time PCR

\begin{tabular}{lll}
\hline Gene & Primers & \\
\hline$\beta$-actin & forward & 5' GGACTCATCGTACTCCTGCTT 3' \\
& reverse & 5' GAGATACTGCTCTGGCTCCT 3' \\
SCl2a1 & forward & 5'CCATCCACCACACTCACCACGC-3' \\
& reverse & 5'GCCCATAAGCACAGCAGCCACA-3' \\
SCl2a4 & forward & 5'-ACATACCTGACAGGGCAAGG-3' \\
& reverse & 5'-CGCCCTTAGTGGTCAGAAG-3' \\
\hline
\end{tabular}

to count ${ }^{3} \mathrm{H}$ radioactivity in the samples using a betacounter (Bekmam - LS 6000TA). The quench caused by sample color was corrected by adding $1000 \mathrm{cpm}$ of ${ }^{3} \mathrm{H}$ triolein, providing proportional correction.

\section{RNA extraction and real-time RT-PCR}

Total RNA from adipose tissue depots were purified using RNeasy Lipid Tissue Mini Kit (QIAGEN, Germany), according to the manufacture's protocol. The integrity of the RNA was assessed using Tris-borate $1.2 \%$ agarose gels stained with ethidium bromide. The amount and purity of the RNA were determined by optical density readings at 260 and $280 \mathrm{~nm}$ (Gene Quant, Amersham-Pharmacia Biotech). Genomic DNA contamination was excluded by running a PCR on the RNA samples. cDNA was obtained from $2 \mu \mathrm{g}$ of total RNA by reverse transcription using an Applied Biosystems kit (High-Capacity cDNA reverse transcription kit) according to the manufacturer's instructions. mRNA expression was determined by real-time RT-PCR (Step One Real-time PCR System, Applied Biosystems, Foster City, CA) using a SybrGreen PCR Master Mix and the specific primers (Table 3).

Gene expression was quantified using the $\Delta \Delta C T$ method by measuring the threshold cycle normalized to $\beta$-actin and then expressed relative to the control groups.

\footnotetext{
Abbreviations

T2DM: Type 2 Diabetes mellitus; CETP: Cholesteryl ester transfer protein, Apo, apolipoproteins; oxLDL: Oxidized LDL.
}

\section{Competing interests}

The authors have no competing interest to disclose.

\section{Authors' contributions}

HCFO designed the study, analyzed data and wrote the manuscript; HFR, $E C V$ and JAB contributed in data acquisition and analyses. HFR drafted the manuscript and all authors revised and approved the article.

\section{Acknowledgments}

This study was supported by grants from Fundação de Amparo à Pesquisa do Estado de São Paulo (\#2011/50400-0, \#2011/51349-8) and Conselho Nacional de Desenvolvimento Científico e Tecnológico (CNPq \# 304532/ 2010-0, \#151197/2013-0). We are especially grateful for the technical assistance of Adriene Alexandra Paiva and Luara Nicolai Piardi.

\section{Author details}

'Department of Structural and Functional Biology, Institute of Biology, State University of Campinas, Unicamp - Cidade Universitária Zeferino Vaz. Rua Monteiro Lobato, 255, Campinas, SP CEP 13083-862, Brazil. ${ }^{2}$ Present address:
Department of Physiological Science, State University of Maringa, Maringa, PR, Brazil.

Received: 5 May 2015 Accepted: 7 January 2016

Published online: 13 January 2016

\section{References}

1. Perley MJ, Kipnis DM. Plasma insulin responses to oral and intravenous glucose: studies in normal and diabetic subjects. J Clin Invest. 1967;46:1954-62.

2. Ginsberg HN. Diabetic dyslipidemia: basic mechanisms underlying the common hypertriglyceridemia and low HDL cholesterol levels. Diabetes. 1996:45 Suppl 3:S27-30.

3. Fisher EA, Feig JE, Hewing B, Hazen SL, Smith JD. High-density lipoprotein function, dysfunction, and reverse cholesterol transport. Arterioscler Thromb Vasc Biol. 2012;32(12):2813-20.

4. Tall AR. Plasma lipid transfer proteins. Annu Rev Biochem. 1995;64:235-57.

5. Tall AR, Yvan-Charvet $L$, Wang $N$. The failure of torcetrapib: was it the molecule or the mechanism? Arterioscler Thromb Vasc Biol. 2007:27:257-60.

6. Goldberg AS, Hegele RA. Cholesteryl ester transfer protein inhibitors for dyslipidemia: focus on dalcetrapib. Drug Des Devel Ther. 2012;6:251-9.

7. Bochem AE, Kuivenhoven JA, Stroes ES. The promise of Cholesteryl Ester Transfer Protein (CETP) inhibition in the treatment of cardiovascular disease. Curr Pharm Des. 2013;19(17):3143-9.

8. de Vries R, Perton FG, Dallinga-Thie GM, van Roon AM, Wolffenbuttel BH, van Tol A, et al. Plasma cholesteryl ester transfer is a determinant of intimamedia thickness in type 2 diabetic and nondiabetic subjects: role of CETP and triglycerides. Diabetes. 2005;54(12):3554-9.

9. López-Ríos L, Nóvoa FJ, Chirino R, Varillas F, Boronat-Cortés M, Wägner AM. Interaction between cholesteryl ester transfer protein and hepatic lipase encoding genes and the risk of type 2 diabetes: results from the Telde study. PLoS One. 2011;6(11):e27208.

10. López-Ríos L, Pérez-Jiménez P, Martínez-Quintana E, Rodriguez González G, Díaz-Chico BN, Nóvoa FJ, et al. Association of Taq 1B CETP polymorphism with insulin and HOMA levels in the population of the Canary Islands. Nutr Metab Cardiovasc Dis. 2011;21(1):18-24.

11. Barter PJ, Rye KA, Tardif JC, Waters DD, Boekholdt SM, Breazna A, et al. Effect of torcetrapib on glucose, insulin, and hemoglobin A1c in subjects in the Investigation of Lipid Level Management to Understand its Impact in Atherosclerotic Events (ILLUMINATE) trial. Circulation. 2011;124(5):555-62.

12. Maclean PS, Tanner CJ, Houmard JA, Barakat HA. Plasma cholesteryl ester transfer protein activity is not linked to insulin sensitivity. Metabolism. 2001: 50(7):783-8.

13. Sladek R, Rocheleau G, Rung J, Dina C, Shen L, Serre D, et al. A genomewide association study identifies novel risk loci for type 2 diabetes. Nature. 2007:445(7130):881-5

14. Schwartz GG, Olsson AG, Abt M, Ballantyne CM, Barter PJ, Brumm J, et al. Effects of dalcetrapib in patients with a recent acute coronary syndrome. $N$ Engl J Med. 2012;367(22):2089-99.

15. Ju X, Cui Q, Zhang M, Wang W, Jiang J, Chang Y, et al. Human cholesteryl ester transfer protein enhances insulin-mediated glucose uptake in adipocytes. Life Sci. 2011;89(13-14):479-84.

16. Cappel DA, Palmisano BT, Emfinger $\mathrm{CH}$, Martinez MN, McGuinness OP Stafford JM. Cholesteryl ester transfer protein protects against insulin resistance in obese female mice. Mol Metab. 2013;2(4):457-67.

17. Jiang XC, Agellon LB, Walsh A, Breslow JL, Tall A. Dietary cholesterol increases transcription of the human cholesteryl ester transfer protein gene intransgenic mice. Dependence on natural flanking sequences. J Clin Invest. 1992;90:1290-5.

18. Raposo HF, Patrício PR, Simões MC, Oliveira HC. Fibrates and fish oil, but not corn oil, up-regulate the expression of the cholesteryl ester transfer protein (CETP) gene. J Nutr Biochem. 2014;25(6):669-74.

19. Jiang XC, Masucci-Magoulas L, Mar J, Lin M, Walsh A, Breslow JL, et al. Down-regulation of mRNA for the low density lipoprotein receptor in transgenic mice containing the gene for human cholesteryl ester transfer protein. Mechanism to explain accumulation of lipoprotein B particles. J Biol Chem. 1993;268(36):27406-12.

20. Oliveira HC, Chouinard RA, Agellon LB, Bruce C, Ma L, Walsh A, et al. Human cholesteryl ester transfer protein gene proximal promoter contains dietary cholesterol positive responsive elements and mediates expression in small intestine and periphery while predominant liver and spleen expression is 
controlled by $5^{\prime}$-distal sequences. Cis-acting sequences mapped in transgenic mice. J Biol Chem. 1996;271(50):31831-8.

21. Bighetti EJ, Patrício PR, Casquero AC, Berti JA, Oliveira HC. Ciprofibrate increases cholesteryl ester transfer protein gene expression and the indirect reverse cholesterol transport to the liver. Lipids Health Dis. 2009;8:50.

22. Cazita PM, Berti JA, Aoki C, Gidlund M, Harada LM, Nunes VS, et al. Cholesteryl ester transfer protein expression attenuates atherosclerosis in ovariectomized mice. J Lipid Res. 2003;44(1):33-40.

23. Siebel AL, Natoli AK, Yap FY, Carey AL, Reddy-Luthmoodoo M, Sviridov D, et al. Effects of high-density lipoprotein elevation with cholesteryl ester transfer protein inhibition on insulin secretion. Circ Res. 2013;113(2):167-75.

24. Ha YC, Barter PJ. Differences in plasma cholesteryl ester transfer activityin sixteen vertebrate species. Comp Biochem Physiol B. 1982;71 (2):265-9.

25. Salerno AG, Silva TR, Amaral MEC, Alberici LC, Bonfleur ML, Patrício PR, et al. Overexpression of apolipoprotein CIII increases and CETP reverses dietinduced obesity in transgenic mice. Int J Obes (Lond). 2007;31(10):1586-95.

26. Briand F, Prunet-Marcassus B, Thieblemont Q, Costard C, Muzotte E, Sordello $S$, et al. Raising HDL with CETP inhibitor torcetrapib improves glucose homeostasis in dyslipidemic and insulin resistant hamsters. Atherosclerosis. 2014;233(2):359-62.

27. Drayna D, Jarnagin AS, McLean J, Henzel W, Kohr W, Fielding C, et al. Cloning and sequencing of human cholesteryl ester transfer protein CDNA. Nature. 1987;327(6123):632-4.

28. Kars M, Yang L, Gregor MF, Mohammed BS, Pietka TA, Finck BN, et al. Tauroursodeoxycholic acid may improve liver and muscle but not adipose tissue insulin sensitivity in obese men and women. Diabetes. 2010;59:1899-905.

29. Harada LM, Amigo L, Cazita PM, Salerno AG, Rigotti AA, Quintão ECR, et al. CETP expression enhances liver HDL-cholesteryl ester uptake but does not alter VLDL and biliary lipid secretion. Atherosclerosis. 2007;191:313-8.

30. Abderrahmani A, Niederhauser G, Favre D, Abdelli S, Ferdaoussi M, Yang JY, et al. Human high-density lipoprotein particles prevent activation of the JNK pathway induced by human oxidised low-density lipoprotein particles in pancreatic beta cells. Diabetologia. 2007;50(6):1304-14.

31. Bonfleur ML, Vanzela EC, Ribeiro RA, de Gabriel DG, de França Carvalho CP, Collares-Buzato CB, et al. Primary hypercholesterolaemia impairs glucose homeostasis and insulin secretion in low-density lipoprotein receptor knockout mice independently of high-fat diet and obesity. Biochim Biophys Acta. 2010;1801(2):183-90.

32. Souza JC, Vanzela EC, Ribeiro RA, Rezende LF, de Oliveira CA, Carneiro EM, et al. Cholesterol reduction ameliorates glucose-induced calcium handling and insulin secretion in islets from low-density lipoprotein receptor knockout mice. Biochim Biophys Acta. 2013;1831(4):769-75.

33. Drew BG, Rye KA, Duffy $S J$, Barter $P$, Kingwell BA. The emerging role of $\mathrm{HDL}$ in glucose metabolism. Nat Rev Endocrinol. 2012;8(4):237-45.

34. Walsh A, Azrolan N, Wang K, Marcigliano A, O'Connell A, Breslow JL. Intestinal expression of the human apoA-l gene in transgenic mice is controlled by a DNA region 3' to the gene in the promoter of the adjacent convergently transcribed apoC-III gene. J Lipid Res. 1993;34(4):617-23.

35. Ishibashi S, Brown MS, Goldstein JL, Gerard RD, Hammer RE, Herz J. Hypercholesterolemia in low density lipoprotein receptor knockout mice and its reversal by adenovirus-mediated gene delivery. J Clin Invest. 1993; 92(2):883-93.

36. Lacy PE, Kostianovsky M. Method for the isolation of intact islets of Langerhans from the rat pancreas. Diabetes. 1967;16(1):35-9.

37. Scott AM, Atwater I, Rojas E. A method for the simultaneous measurement of insulin release and B-cell membrane potential in single mouse islets of Langerhans. Diabetologia. 1981;21:470-5.

38. Cooney GJ, Caterson ID, Newsholme EA. The effect of insulin and noradrenaline on the uptake of 2-[1-14C]deoxyglucose in vivo by brown adipose tissue and other glucose-utilising tissues of the mouse. FEBS Lett. 1985;188(2):257-61.

\section{Submit your next manuscript to BioMed Central and we will help you at every step:}

- We accept pre-submission inquiries

- Our selector tool helps you to find the most relevant journal

- We provide round the clock customer support

- Convenient online submission

- Thorough peer review

- Inclusion in PubMed and all major indexing services

- Maximum visibility for your research

Submit your manuscript at www.biomedcentral.com/submit
() BioMed Central 